\title{
SOME FUNDAMENTAL JURISDICTIONAL CONCEPTIONS AS APPLIED IN JUDGMENT CONVENTIONS
}

\section{Ralf Michaels}

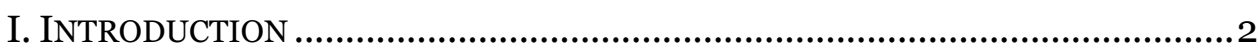

II. FUNDAMENTAL CONCEPTS...................................................................... 4

1. Required, Excluded, and Permitted Bases .......................................... 5

2. Direct and Indirect Jurisdiction .......................................................

3. Single and Double Conventions .........................................................11

4. Mixed Conventions ................................................................................. 13

III. THE NINE POSSIBLE CATEGORIES FOR BASES OF

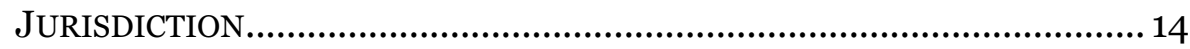

1. Required-Required ............................................................................ 17

2. Required-Permitted ............................................................................. 17

3. Required-Excluded ...................................................................... 18

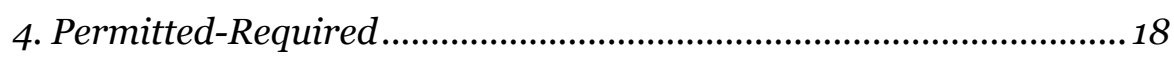

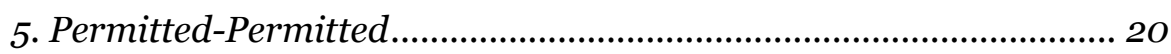

6. Permitted-Excluded .......................................................................... 21

7. Excluded-Required ................................................................................22

8. Excluded-Permitted ..........................................................................22

9. Excluded-Excluded ............................................................................23

IV. A NEW TyPOLOGY OF CONVENTIONS ..................................................24

1. State of Nature …..................................................................................24

2. Single and Double Conventions ........................................................25

3. Pure and Mixed Conventions .............................................................27

4. Positive, Negative, and Bivalent Conventions ................................28

5. Symmetric and Asymmetric Conventions .........................................3

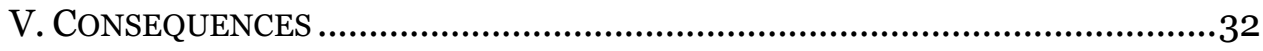




\section{INTRODUCTION}

Arthur von Mehren's last and most ambitious project, a Hague Convention unifying rules on international jurisdiction and foreign judgments, did not come to fruition. One reason were prevailing differences over substantive issues, that have been discussed at length. ${ }^{1}$ Yet such differences might have been overcome through compromise, had there not been a problem that has received less attention but may have been more fundamental precisely because it was not fully recognized: Most delegates implicitly presumed that judgments conventions must take on a certain shape. One such presumption that has been discussed was that all jurisdictional bases in a Convention must be either required (so courts in all member states must exercise jurisdiction under certain circumstances), or excluded (so courts are not allowed to exercise jurisdiction under certain circumstances). A second assumption, less well recognized, was that Conventions that regulate jurisdiction in addition to recognition and enforcement of judgments must be symmetrical: If a judgment rests on a required basis of jurisdiction, other states must be obliged to enforce it (unless there are other reasons not to enforce it, such as fraud); if it rests on an excluded basis, other states must be restrained from enforcing it.

Both assumptions are wrong, and Arthur von Mehren has worked tirelessly to show this. The alternative he developed was the mixed convention, an ingenious model to bridge the gap between simple enforcement conventions that regulate only the recognition of foreign judgments and double conventions that regulate jurisdiction both at the decision and at the recognition stage. ${ }^{2}$ This concept formed the basis of the US proposal at the Hague. ${ }^{3}$ Yet

\footnotetext{
${ }^{1}$ Elsewhere I argue that some of these differences arise because Americans and Europeans argue about jurisdiction from different paradigms: Ralf Michaels, Two Paradigms of Jurisdiction, 26 MicH. J. INT'L L. _ (2006).

${ }^{2}$ Arthur T. von Mehren, Recognition of United States Judgments Abroad and Foreign Judgments in the United States: Would an International Convention Be Useful?, 57 RabelsZ 449, 456-9 (1993); Arthur T. von Mehren, Recognition and Enforcement of Foreign Judgments: A New Approach for the Hague Conference?, 57 LAW \& ConTEMP. PROBS. 271, 282-7 (1994) (hereinafter von Mehren, New Approach); Arthur T. von Mehren, The Case for a Convention-mixte Approach to Jurisdiction to Adjudicate and Recognition and Enforcement of Foreign Judgments, 61 RABELS ZEITSCHRIFT FÜR AUSLÄNDISCHES UND INTERNATIONALS PRIVATRECHT (RABELSZ) 86 (1997) (hereinafter von Mehren, Case); Arthur T. von Mehren, Enforcing Judgments Abroad: Reflections on the Design of Recognition Conventions, 24 BROOK. J. INT'L L. 17 (1998) (hereinafter von Mehren, Design); Arthur T. von Mehren, Drafting a Convention on International Jurisdiction and the Effects of Foreign Judgments Acceptable Worldwide: Can the Hague Conference Project Succeed?, 49 AM. J. CoMP. L. 191, 196-202 (2001) (hereinafter von Mehren, Drafting).

3 See Some Reflections of the Permanent Bureau on a General Convention on Enforcement of Judgments, in I Hague CONFERENCE on Private InTERnational LaW, ProceEdings of the SEVENTEENTH SESSION 231, 235 (1995); Conclusions of the Working Group Meeting on Enforcement of Judgments, ibid. at 257.
} 
other delegations, especially European ones, opposed the concept ${ }^{4}$ and preferred to work on a true double convention after the model of the 1968 Brussels Convention 5 . The mixed convention model was ultimately adopted in a draft of $1999,{ }^{6}$ but only half-heartedly and too late to save the project. Although the delegates have since concluded a much-reduced Convention on Choice of Court Agreements, ${ }^{7}$ the much more ambitious early project of a fullfledged judgment convention has failed, at least for the time being. In hindsight it appears delegates never fully understood the implications of the mixed convention and the possibilities it ensued. ${ }^{8}$ By presuming until the end that certain shapes of rules are somehow necessary, delegates did not realize the full array of possible rules. The failure of negotiations was the consequence not only of policy differences, but also of a lack of conceptual clarity.

Once, the analysis of rights suffered from a similar lack of conceptual clarity, and of erroneous perceptions that rights must take on a certain shape. These erroneous perceptions were dispelled by Wesley N. Hohfeld's seminal work on the categorization of rights. 9 Hohfeld's analysis is purely analytical; his dissection of different kinds of what he calls jural relations has no direct implications for policies. This is why he has sometimes been thought of as a legal formalist without relevance for policies and social engineering ${ }^{10}$. The

\footnotetext{
${ }^{4}$ International Jurisdiction and Foreign Judgments in Civil and Commercial Matters - Report drawn up by Catherine Kessedjian, Hague Conference ON PRIVATE InTERnATIONAL LAW ENFORCEMENT OF JUDGMENTS, PREL. DOC. NO. 7 (April 1997), available at http://www.hcch.net/upload/wop/jdgm_pd7.pdf, pp. 43-4, nos. 151-6.

51968 Brussels Convention on jurisdiction and the enforcement of judgments in civil and commercial matters (consolidated version), 1998 O.J. C-27/1.

${ }^{6}$ See Preliminary Draft Convention on Jurisdiction and Foreign Judgments in Civil and Commercial Matters, adopted by the Special Commission on 30 October 1999, available at http://www.hcch.net/upload/wop/jdgmpd11.pdf, Article 17; see also Report of the Special Commission drawn up by Peter Nygh and Fausto Pocar, ibid. at 19, 28-9.

7 (Hague) Convention on Choice of Court Agreements (Concluded 30 June 2005), available at http://www.hcch.net/index_en.php?act=conventions.text\&cid $=98$, published with an introductory note by Ronald A. Brand in 44 I.L.M. 1291 (2005). See Christian Thiele, The Hague Convention on Choice of Court Agreements - Was it Worth the Effort?, in this volume,

8 Arthur T. von Mehren \& Ralf Michaels, Pragmatismus und Realismus für die Haager Verhandlungen zu einem weltweiten Gerichtsstands- und Vollstreckungsübereinkommen, 25 DAJVNEWSLETTER 124, 127 (2000); Arthur T. von Mehren, The Hague Jurisdiction and Enforcement Convention Project Faces an Impasse - A Diagnosis and Guidelines for a Cure, 20 PRAXIS DES INTERNATIONALEN PRIVAT- UND PROZESSRECHTS [IPRAX] 465 (2000); Arthur T. von Mehren, Drafting, supra note 2 , at 196-200.

9 Wesley N. Hohfeld, Some Fundamental Legal Conceptions as Applied in Legal Reasoning, 23 YALE L.J. 16 (1913); reprinted in FUNDAMENTAL LEGAL CONCEPTIONS AS APPLIED IN JUDICIAL REASONING BY WESLEY NEWCOMB HoHFELD (David Campbell \& Philip Thomas eds., 2001).

${ }^{10}$ See Duncan Kennedy \& Frank Michelman, Are Property and Contract Efficient?, 8 HofSTRA L. REV. 711, 751-2 (1980); Nigel E. Simmonds, Introduction, in FundamENTAL LEGAL ConcePtions, supra note 9 , at $\mathrm{x}$-xii.
} 
opposite is true. "Hohfeld intended ... not to resolve questions such as those which would interest the formalist, but to provide the fundamental analysis which he saw as an essential prerequisite to the resolution of such questions."11 Clear concepts do not guarantee proper policy debates, but without clear concepts policy debate is impossible.

A similar conceptual analysis is still lacking from the law of jurisdiction, although it is urgently needed, as the failure of the Hague negotiations has arguably shown. ${ }^{12}$ This essay begins to fill this gap and do for the analysis of jurisdiction what Hohfeld has done for the analysis of rights. Its primary aim is analytical, not normative; it deals with concepts and their logical interrelations, not with policies of jurisdiction and of recognition. Nonetheless, such an analysis has important implications for policy analysis. First, it shows that the array of possible categories of jurisdiction, and thus the possibilities for compromise, are considerably bigger than delegates and analysts have previously assumed. The article uses examples from numerous conventions to show that the various categories are not merely theoretical but actually exist. Second, the analysis makes it possible to isolate different policy considerations and thereby make a structured debate of different interests easier. In discussing the different concepts and categories, this article will point some of these interests out.

\section{FUNDAMENTAL CONCEPTS}

Hohfeld provided three important insights to the conceptualization and classification of rights. First, rights are not abstract attributes of rightholders. Rather, a right represents one side of a "jural relation" between persons, and the flipside of the rightholder's right is a certain position on the side of the oblige. Second, "right" can mean very different things. Hohfeld distinguished four types - rights (or claim-rights), privileges, powers and immunities. Especially important was the introduction of privileges and immunities where others had seen an absence of rights. It enabled Hohfeld to categorize every possible situation legally - there is no situation without jural relations. Third,

\footnotetext{
${ }^{11}$ Simmonds, supra note 10 , at xii.

12 Von Mehren himself did not lay out a full-fledged conceptual analysis, certainly due to his preference for pragmatism and policy debates over abstract conceptual discussions; see Peter D. Trooboff, In Memoriam: Arthur von Mehren, 119 HARV. L. REv. 1966, 1970-1 (2006). However, an invaluable conceptual presentation is von Mehren, Design, supra note 2; see also Arthur T. von Mehren, Jurisdictional Requirements: To What Extent should the State of Origin's Interpretation of Convention Rules Control for Recognition and Enforcement Purposes? (hereinafter von Mehren, Jurisdictional Requirements), in The Hague CONVENTION ON JURISDICTION AND JUdGMENTS A-29 (Andreas F. Lowenfeld \& Linda J. Silberman eds., 2001).
} 
while relations of correlation and opposition exist between specific pairs, ${ }^{13}$ other relations than those of correlation and of opposition are not intrinsic to rights. In particular, privileges and rights are independent from each other a party may have a privilege of a certain conduct but no claim-right to enforce it, or a claim-right against others to refrain from interference but no privilege to engage in that conduct. ${ }^{14}$

Jurisdiction is different from rights (although the legal relations it creates can be modeled in Hohfeldian terms). Nonetheless, von Mehren's insights on the relation between jurisdiction and enforcement provide strikingly similar insights. This section will formalize these thoughts, and the concept of the mixed convention, in three separate steps.

\section{Required, Excluded, and Permitted Bases}

A first issue concerns the design of judgments conventions, more specifically the structure of rules on individual bases of jurisdiction. Different types of rules were not normally distinguished before von Mehren developed the mixed convention with the concepts of required, excluded and permitted bases of jurisdiction, or white, black, and gray zones..$^{15}$

Rules in the white zone require certain bases of jurisdiction. ${ }^{16}$ For example, Article 5(1) of the Brussels Regulation requires states to provide jurisdiction for contracts at the place of performance. Article 5 of the 1978 Hague Judgments Convention ${ }^{17}$ obliges member states to enforce foreign judgments if those judgments rested on one of the bases of jurisdiction listed in Articles 10 and 11. Rules in the black zone exclude certain bases of jurisdiction. An example for a rule excluding bases of direct jurisdiction is Article 3(2) of the Brussels Regulation that explicitly excludes certain national exorbitant bases of direct jurisdiction. The Supplementary Protocol to the 1971 Hague

\footnotetext{
13 For a table of these, see Simmonds, supra note 10, at xii.

${ }^{14}$ See ibid. at xix $-\mathrm{xx}$.

15 These three categories appear first in von Mehren, New Approach, supra note 2, 283. A different color scheme sometimes found (green, red, and yellow) was proposed by Andreas Lowenfeld, Thoughts About a Multinational Judgments Convention: A Reaction to the von Mehren Report, 57 LAW \& CONTEMP. PROBS. 289 (1994).

${ }^{16}$ Whether a convention requires national legal systems to provide for certain bases, or whether a convention itself provides for these bases, is irrelevant for purposes of the analysis.

17 Convention of 1 February 1971 on the Recognition and Enforcement of Foreign Judgments in Civil and Commercial Matters, available at http://hcch.evision.nl/index_en.php?act=conventions.text\&cid=78.
} 
Judgments Convention ${ }^{18}$ contains, in its Article 4, a list of exorbitant bases of jurisdiction that Article 2(1) declares excluded from enforcement.

Von Mehren's important contribution was to show that there is a third, gray zone of jurisdictional bases which are neither required nor excluded: the permitted bases of jurisdiction. States to decide whether they want to adopt these bases or not. This freedom for states distinguishes these bases both from the required bases placed in the white category and from the excluded bases placed in the black category, both of which are binding on states. Permitted bases of direct jurisdiction leave it up to states whether they want to assert jurisdiction on the basis of certain criteria. Such rules had existed for quite some time. For example, Brussels Article 4(1) provides for permission of all bases of national law against defendants not domiciled in a member state. Nonetheless, before von Mehren introduced them in the context of the mixed convention, this category had largely escaped scholars' attention. The reason may be that in the absence of regulation all bases of jurisdiction are permitted. Scholars may have wished to confine the notion of regulation to required and excluded bases, just as attention in the area of rights was long confined to duties and claim-rights, while liberties were ignored. But just as Hohfeld made clear that liberties are important legal relations, von Mehren made clear that permitted bases of jurisdiction create an important zone of jurisdictional bases.

Although the importance of the gray category of permitted bases has often been emphasized, it becomes fully clear only once the analysis of jurisdictional bases is linked to deontic logic. The three values - required, permitted, and excluded - reflect the traditional threefold classification of normative statuses in deontic logic of obligatory, optional, and impermissible. ${ }^{19}$ This means that, like the latter three categories in deontic logic, so required, permitted, and excluded contain all possible statuses of jurisdictional bases. Every jurisdictional basis must in every legal system, and in every convention, be either required, permitted, or excluded. This is true even for bases that are not explicitly regulated in the convention.

Some conventions make the status of such bases explicit. For example, Article 3(1) of the Brussels Regulation makes clear that, as against member states domiciliaries as defendants, all jurisdictional bases not required by the Convention are excluded. It follows logically that no other bases are permitted; the explicit exclusion of certain bases in Article 3(2) does not add anything in this regard. Other conventions are not explicit, so interpretation

\footnotetext{
${ }^{18}$ Supplementary Protocol of 1 February 1971 to the Convention on the Recognition and Enforcement of Foreign Judgments in Civil and Commercial Matters, available at http://hcch.evision.nl/index_en.php?act=conventions.text\&cid=79.

19 For the relation between these three deontological categories and Hohfeld's scheme, see Andrew Halpin, Fundamental Legal Conceptions Reconsidered, 16 CAN. J.L. \& JURIS. 41 (2003).
} 
is required to determine their exact substance. For example, Article 4(1) of the 1971 Hague Judgments Convention mentions only required bases of indirect jurisdiction. ${ }^{20}$ Whether other bases are permitted or excluded does not become clear from the wording alone. The uncertainty disappears, however, in view of the Protocol to the Convention, which adds a number of excluded bases of jurisdiction in its Article 4. Ordinary principles of interpretation suggest that all bases that are neither explicitly required nor explicitly excluded are permitted. Whether interpretation is necessary or not does not change the mutual exclusivity of these three categories - ultimately, a basis can only have one of these three values.

A quick look at policy impacts shows how helpful the gray category would have been for negotiations. Generally, required bases favor plaintiffs, while excluded bases favor defendants. Without the gray category of permitted bases, this means that delegates must not only agree for every basis of jurisdiction whether it is good and should be required, or whether it is bad and should be excluded; they must also always have the overall balance between plaintiffs and defendants in view. This is almost impossibly complex. By contrast, once bases can be left in the gray area, it becomes possible to negotiate over individual bases of jurisdiction without having to agree on every single one of them. This makes negotiations much easier and the consequences of conventions on the balance between plaintiff and defendant interests easier to predict. For example, delegates at the Hague perhaps spent an undue amount of time trying to find a basis for jurisdiction over corporations, instead of just leaving both the US basis of doing business and the European basis for subsidiaries in the gray area.

\section{Direct and Indirect Jurisdiction}

A second issue concerns the role that jurisdiction plays. The issue whether a court has adjudicatory jurisdiction ${ }^{21}$ can become relevant at two different stages. The first stage concerns the proceedings before the court that renders the original decision, hereinafter called the rendering court. The rendering court will not hear a case, much less render a decision, unless it determines that it has jurisdiction to do so. ${ }^{22}$ The second stage concerns the proceedings

\footnotetext{
20 "A decision rendered in one of the Contracting States shall be entitled to recognition and enforcement in another Contracting State under the terms of this Convention - (1) if the decision was given by a court considered to have jurisdiction within the meaning of this Convention ..."

${ }^{21}$ In using "adjudicatory jurisdiction" rather than "judicial jurisdiction", I follow Arthur T. von Mehren, Adjudicatory Jurisdiction: General Theories Compared and Evaluated, 63 B.U. L. REV. 279, 282-3 (1983) (Adjudicatory Jurisdiction).

22 If it renders a decision despite the lack of jurisdiction, an appellate court may declare the decision void. For the sake of simplicity, this is here treated as though the first instance court applied the law correctly.
} 
before the court requested to recognize and/or enforce the, hereinafter the requested court. ${ }^{23}$ The requested court will not recognize or enforce the decision of the rendering court unless it determines that the rendering court had jurisdiction. ${ }^{24}$

Use of the same term - jurisdiction - at both stages suggests uniformity of concepts. That suggestion may be illusory, just as the use of the term "right" conceals differences between different concepts. A conceptual clarification is needed. French law has found a particularly successful terminology to resolve this concern by distinguishing two concepts: direct jurisdiction (compétence directe) and indirect jurisdiction (compétence indirecte). ${ }^{25}$ Direct jurisdiction describes the question for the rendering court, since only the rendering court is directly engaged with the question whether it should exercise jurisdiction or not. Indirect jurisdiction describes the question for the requested court, since that court can control only indirectly, ${ }^{26}$ through the recognition procedure, whether jurisdiction was properly exercised or not.

Of course the terminological distinction does not provide an answer to the substantive issue: Is the question whether the rendering court had jurisdiction the same question when asked by the rendering and when asked by the requested court? And is the question the requested court asks for recognition purposes the same question it would ask if it were the adjudicating court?

\footnotetext{
23 The second court must also decide whether it has direct jurisdiction over the enforcement litigation. This question is not part of the analysis here. See Dennis Solomon, Internationale Zuständigkeit zur Vollstreckbarerklärung ausländischer Entscheidungen - Divergierende Tendenzen in Deutschland und den Vereinigten Staaten, DIE AKTIENGESELLSCHAFT (AG) (2006). (1987).

24 Hilton v. Guyot, 159 U.S. 113, 202; Restatement (Third) Foreign Relations Law § 482(1)(b)

25 ETIENNE BARTIN, ETUDES SUR LES EFFETS INTERNATIONAUX DES JUGEMENTS 4-5 (1907); BARTIN, PRINCIPES DE DROIT INTERNATIONAL PRIVE 317, § 127 (1930). Bartin distinguished only the concepts, not the relevant policies. For occasional use of this terminology in the US, see Arthur Nussbaum, Jurisdiction and Foreign Judgments, 41 ColuM. L. REV. 221, 225 (1941); 225; Ronald A. Brand, Enforcement of Judgments in the United States and Europe, 13 J.L. \& COMMMERCE 193, 201-2 (1994); Eugene F. Scoles, Peter Hay, Patrick J. Borchers, Symeon C. Symeonides, Conflict of LaWs 288 n.21 ( $4^{\text {th }}$ ed. 2004); for occasional use in Germany, see JAN KROPHOLLER, INTERNATIONALES PRIVATRECHT 565 ( $4^{\text {th }}$ ed. 2001); GERHARD KEgEL \& KLAUS SCHURIG, INTERNATIONALES PRIVATRECHT 1062 ( $9^{\text {th }}$ ed. 2004).

Other terminologies are less successful. German lawyers distinguish between decision jurisdiction and recognition jurisdiction (Entscheidungszuständigkeit and Anerkennungszuständigkeit). See HAIMO SCHACK, INTERNATIONALES ZIVILVERFAHRENSRECHT 87, no. 187 ( $3^{\text {rd }}$ ed. 2002). But "decision recognition" does not make clear sufficiently that what is at stake is the jurisdiction of the rendering, not that of the requested court. Another German proposal is to distinguish rules of conduct and rules of evaluation (Befolgungsregeln and Beurteilungsregeln). See WALTER JELLINEK, DIE ZWEISEITIGEN STAATSVERTRÄGE ÜBER ANERKENNUNG AUSLÄNDISCHER ZIVILURTEILE 26 (1953). But evaluation is a task of both the rendering and the recognizing court.

${ }^{26}$ SCOLES ET AL., supra note 25, at 288 (“indirect restraints on jurisdiction").
} 
Many authors assume the standard for direct and indirect jurisdiction to be the same; ${ }^{27}$ so do many legal orders. ${ }^{28}$ This is true for sister-state judgments in a federal or quasi-federal system ${ }^{29}$ under the U.S. Constitution ${ }^{30}$ and the Brussels Regulation ${ }^{31}$; it is true internationally for both the 1999 Hague Preliminary Draft Convention on Jurisdiction and Foreign Judgments and the 2005 Hague Convention on Choice of Court Agreements. Lord Justice Hodson put the matter like this: "It must surely be that what entitles an English court to assume jurisdiction must be equally effective in the case of a foreign court." 32 Article 328(1) of the German Civil Code contains a similar reciprocity rule. 33

Take for example the famous Yahoo! case. A French court asserted jurisdiction over the US corporation Yahoo! on the mere basis that its web site was accessible from French computers 34 . This contact was sufficient for jurisdiction under French law but would likely not be sufficient under U.S. law. ${ }^{35}$ One

\footnotetext{
${ }^{27}$ E.g. BARTIN, PRINCIPES DE DROIT INTERNATIONAL PRIVE, 317, 548 et seq. (1930); Paul Neuhaus, Internationales Zivilprozessrecht und Internationales Privatrecht, 20 RABELSZ 201, 225 (1955); REINHOLD GEIMER, ZUR PRÜFUNG DER GERICHTSBARKEIT UND DER INTERNATIONALEN ZUSTÄNDIGKEIT BEI DER ANERKENNUNG AUSLÄNDISCHER URTEILE 106 (1966); DOMINIQUE HOLLEAUX, COMPÉTENCE DU Juge ÉTRANGER ET RECONNAISSANCE DES JUGEMENTS 121 (1970). GARY B. BORN, INTERNATIONAL CIVIL LITIGATION IN UNITED STATES COURTS 970-1 ( $3^{\text {rd }}$ ed. 1996) discusses indirect jurisdiction as a choice between the rendering and the requested court's law on direct jurisdiction. Von Mehren calls such approaches "derivative" theories: Arthur T. von Mehren, Recognition and Enforcement of Foreign Judgments - General Theory and the Role of Jurisdictional Requirements, 167 ACADEMY OF INTERNATIONAL LAW, RECUEIL DES COURS (1980-II) 9, 56-7 (1980, published 1981) (hereinafter von Mehren, General Theory).

28 See Arthur T. von Mehren \& Donald T. Trautman, Recognition and Enforcement of Foreign Adjudications: A Survey and a Suggested Approach, 81 HARV. L. REV. 1601, 1607 (1968).

29 Arthur T. von Mehren, Recognition and Enforcement of Sister-State Judgments: Reflections on General Theory and Current Practice in the European Economic Community and the United States, 81 COLUM. L. REV. 1044 (1981).

${ }^{30}$ U.S. Const. Art. IV, § 1 (Full Faith and Credit Clause).

${ }^{31}$ Council Regulation (EC) No 44/2001 of 22 December 2000 on Jurisdiction and the Recognition and Enforcement of Judgments in Civil and Commercial Matters, 2001 O.J. L 12/1.

$3^{2}$ Travers $v$. Holley, [1953] P. 246, 256 (C.A.).

33 Peter L. Murray \& Rolf StÜRner, German Civil Justice 530-2 (2004); specifically for U.S judgments, see Wolfgang Wurmnest, Recognition and Enforcement of U.S. Money Judgments in Germany, 23 BERKELEY J. INT'L L. 175, 186-8 (2005); CHRISTOPH SCHÄRTL, DAS SPIEGELBILDPRINZIP IM RECHTSVERKEHR MIT AUSLÄNDISCHEN STAATENVERBINDUNGEN UNTER BESONDERER BERÜCKSICHTIGUNG DES DEUTSCH-AMERIKANISCHEN RECHTSVERKEHRS 264-71 (2005).

34 UEJF et Licra c. Yahoo! Inc. et Yahoo France 22 mai 2000 (Tribunal de Grande Instance Paris), 2000 COMMUNICATION ET COMMERCE ELECTRONIQUE (COMM. COM. ÉLECTR. comm. $\mathrm{n}^{\circ}$ 92, note JChr. Galloux; also available at http://www.juriscom.net/txt/jurisfr/cti/tgiparis20000522.htm; English translation available at http://www.juriscom.net/txt/jurisfr/cti/yauctions20000522.htm.

35 For a comparison of European and US approaches, see Patrick J. Borchers, Tort and Contract Jurisdiction via the Internet: The 'Minimum Contacts' Test and the Brussels Regulation Compared,
} 
question was whether the French court rightfully asserted jurisdiction, another, whether US courts would have to recognize and enforce the ensuing decision. Many commentators in the U.S. addressed both questions together. One set of commentators denied the French court's jurisdiction over Yahoo, typically invoking not French law but either US law or some universal standards; these commentators consequently denied a duty of US courts to enforce the decision. ${ }^{36}$ Another set of commentators asserted that French courts had jurisdiction over Yahoo!, and US courts therefore had to recognize the ensuing decision 37 . Very few authors took the middle way, according to which French courts had jurisdiction according to French law, but US courts had no duty to enforce the ensuing decision under either US or international law.

Yet, although it is of course possible to use the same standard, it is by no means necessary to do so, ${ }^{38}$ A Hohfeldian reconception makes clear that direct and indirect jurisdiction are different and unconnected kinds of legal position. Between states, direct jurisdiction is a privilege -the courts of state $\mathrm{A}$ are free to exert direct jurisdiction, and state $\mathrm{B}$ has no right (the opposite of a privilege) that state A refrain from that jurisdiction. Indirect jurisdiction, by contrast, is a power - if the courts of state A have indirect jurisdiction, they bind the courts of state B with the ensuing judgment (a "liability" of state B in Hohfeldian terms). Powers and privileges can be connected in a legal system, but - this is important - there is no logical connection between them. The courts of state A may have direct but not indirect jurisdiction, and vice versa.

This insight is important, because, assuming states are interested in maximizing their freedom to render decisions, a surprising asymmetry between indirect and direct jurisdiction exists. States are constrained more by excluded than by required bases of jurisdiction, but more by required than by excluded bases of indirect jurisdiction. Realizing that direct and indirect jurisdiction can be regulated differently opens up enormous possibilities for refined policy considerations, 39 because it can account for this asymmetry. On the one hand, states may find it important to secure access to their courts and

50 NETh. INT'L L. REV. 401 (2003). Note that the French decision in the Yahoo! case was based on French domestic law, not the Brussels Regulation.

$3^{6}$ Cf. Marc H. Greenberg, A Return to Lilliput: The LICRA v. Yahoo! Case and the Regulation of Online Content in theWorld Market, 18 BERKELEY TECH. L.J. 1191, 1205 ("Little will be accomplished if the boundaries of jurisdiction are expanded without concurrently expanding the ability to enforce judgments obtained in those foreign courts.")

37 Cf. Paul Schiff Berman, Towards a Cosmopolitan Vision of Conflict of Laws: Redefining Governmental Interests in a Global Era, 153 U. PA. L. REV. 1819, 1879 (“...I think that the extent of Yahoo!'s business activities abroad justify the French judgment and should make it enforceable in the United States.", emphases added).

$3^{8}$ Von Mehren \& Trautman, supra note 28, at 1610-36; von Mehren, General Theory, supra note 25. For an earlier very clear analysis, see Nussbaum, supra note 25.

39 See the debate in von Mehren, General Theory, supra note 25, at 55-74. 
therefore provide certain bases of direct jurisdiction, but accept that other states do not recognize ensuing decisions, and perhaps even reject foreign judgments rendered on such bases. Tag jurisdiction for human rights violation could be an example. On the other hand, states may be ready to accept certain bases of indirect jurisdiction, even though they do not use the same bases of direct jurisdiction - perhaps because they have other, functionally equivalent, bases.

It may be that the perceived need for symmetry was a problem for the Hague negotiations. For example, it seems plausible that European law contains more excluded bases both for direct and for indirect jurisdiction than US law. If this is so, then accepting an asymmetric convention would have enabled Europeans to agree to more required bases of indirect jurisdictions in return for the US agreeing to more excluded direct bases of jurisdiction. There was no need to agree on similar rules for both direct and indirect jurisdiction.

\section{Single and Double Conventions}

Both distinctions - that between required, excluded and permitted bases jurisdiction, and that between direct and indirect jurisdiction - come together in the design of judgments conventions. Traditionally, single and double conventions were distinguished. However, it is not always clear what these terms mean. Closer analysis reveals that two different understandings of the distinction are blurred in debate, understandings that can, but need not, coincide.

In the first understanding, single conventions regulate only indirect jurisdiction, ${ }^{40}$ while double conventions regulate both direct and indirect jurisdiction. Single conventions in this sense were the standard type before the Brussels Regulation; the 1971 Hague Judgments Convention is but one of many examples. By contrast, the Brussels Convention provides the most important example of such a double Convention. Original plans had been for a single convention that would have regulated only indirect jurisdiction, as Article 220 of the EC Treaty provided..$^{4}$ Yet a Belgian scholar, Martha Weser, managed to convince the drafters of the advantages of also regulating direct

\footnotetext{
40 A convention that regulates only direct jurisdiction is a single convention in this sense as well, though these are rarely discussed. But see Arthur Taylor von Mehren, Theory and Practice of Adjudicatory Authority in Private International Law: A Comparative Study of the Doctrine, Policies and Practices of Common- and Civil-Law Systems, 295 RECUEIL DES COURS (2002) 9, 404-5 n.1300 (2003) (hereinafter von Mehren, Theory and Practice); see also infra IV.2.

${ }^{41}$ Treaty Establishing the European Community (1957), Art. 220; 51 AM. J. INT’L L. 865 (1957):

Member States shall, as far as necessary, engage in negotiations with each other with a view to ensuring for their nationals ... the simplification of the formalities governing the reciprocal recognition and execution of judicial decision and arbitral awards.
} 
jurisdiction, ${ }^{42}$ drawing on experience from earlier conventions to which Belgium was a party. 43 As a consequence, the Brussels Convention and its successor, the Brussels Regulation, regulate both indirect and direct jurisdiction, even though they do so by different techniques. Regarding direct jurisdiction, the Regulation contains individual specific bases in its Articles 2, $5 \mathrm{ff}$. Regarding indirect jurisdiction, the Regulation contains no such list of individual bases, but rather regulates the issue implicitly: lack of indirect jurisdiction is not one of the grounds for non-recognition listed in Articles 34, 35(1),44 and Article 35(1) makes clear that lack of indirect jurisdiction cannot even be invoked as a violation of public policy. 45

There is, however, a second understanding of the difference between simple and double conventions. It refers to the issue whether a convention only requires certain bases of jurisdiction - then it is a simple convention - or whether it also excludes certain bases of jurisdiction - then it is a double convention. ${ }^{46}$ The Hague Judgments Convention of 1971 and the Brussels Regulation provide good examples of this second understanding, too. The bases of jurisdiction required in Articles 10 and 11 of the 1971 Hague Convention are the only bases mentioned in the Convention, and the list is not mean to be exclusive. It follows that no bases of direct jurisdiction are excluded (or, put differently, all other bases are permitted). And no bases of indirect jurisdiction are excluded, either: if a judgment rests on a basis not included in Articles 10 and 11, the requested court is free, but not obliged, to deny jurisdiction. The Brussels Regulation is different in this regard. In addition to requiring certain bases of direct jurisdiction, it also excludes certain bases. Articles 2(1), 3(1) make clear that the required bases of direct

42 See, especially, Martha Weser, Les Conflits de jurisdictions dans le cadre du Marché Commun. Difficultés et remèdes, published in six installments in 48 REVUE CRITIQUE DE DROIT INTERNATIONAL PRIVE (REV. CRIT.) 613 (1959), 49 REV. CRIT. 21, 151, 313, 533 (1960), 50 REV. CRIT. 195 (1961); MARTHA WESER, CONVENTION COMMUNAUTAIRE SUR LA COMPETENCE JUDICIAIRE ET L'EXECUTION DES DECISIONS 49-84 (1975). On Weser's influence see Arthur Bülow, Vereinheitlichtes Internationales Zivilprozessrecht in der Europäischen Wirtschaftsgemeinschaft, 29 RABELSZ 473, 479 n.18; GEORGES A.L. DROZ, COMPETENCE JUDICIAIRE ET EFFETS DES JUGEMENTS DANS LE MARCHE COMMUN 7-8 (1972); see also Pierre Bellet, L'Elaboration d'une Convention sur la Reconnaissance des Jugements dans le Cadre du Marché Commun, 92 Journal DU DROIT InTERNATIONAL (J.D.I.) 833, 846-7 (1965).

43 Franco-Belgian Enforcement Treaty, Aug 8, 1899 (see MARTHA WESER, Traite FRANCO-BELGE DU 8 JUILLET 1899 (1951)); Belgian-Dutch Enforcement Treaty, Mar 28, 1925 ; Benelux Treaty, Nov. 24, 1961. Martha Weser was prominently involved in the drafting both of the Benelux Treaty of 1961 and, as observer, of the Brussels Convention. See Raymond Vander Elst, Préface, in WESER, CONVENTION COMMUNAUTAIRE, supra note 42 , at IX.

44 These are largely equivalent to Brussels Convention Arts. 27, 28(1).

45 Case C-7/98, Krombach v. Bamberski, 2000 E.C.R. I-1935; (on Article 28(1) of the Brussels Convention); for Article 35(3), see Bundesgerichtshof [BGH] [Federal Court of Justice] Oct 6, 2005, IX ZB 27/O2 (Ger.); for intertemporal applicability, see BGH March 30, 2006, IX ZB 102/04 (Ger.).

46 Von Mehren, Design, supra note 2, at 19. Logically, a convention that only excludes certain bases of jurisdiction without requiring others would be a single convention in this sense as well. 
jurisdiction listed in Articles 2, 5-24 are the only bases available against defendants domiciled in the EU; Article 3(2) in combination with Annex I explicitly declares certain national bases of jurisdiction inapplicable in this context. In other words, every basis of direct jurisdiction is either a required or an excluded basis.

The examples show that both understandings can overlap. The 1971 Hague Convention is a simple convention in both senses of the word, and the Brussels Regulation is a double convention in both senses of the word. Perhaps the respective overlap of both concepts of single and double conventions respectively is no coincidence. Delegates may be psychologically inclined to enter into negotiations that combine either the simple or the double character in both senses. Thus, it may seem to make little sense to exclude certain bases of jurisdiction from conventions that deal merely with indirect jurisdiction. After all, the goal of such conventions is to make enforceability easier rather than harder. On the other hand, it may seem to make sense to devise lists of required bases of jurisdiction in conventions dealing with both direct and indirect jurisdiction.

Yet psychological inclinations can stand in the way of recognizing logical connections and possibilities, and logically, both criteria are independent of each other. It is possible to create a convention that deals only with indirect jurisdiction (simple convention in the first sense) but does so by both requiring some and excluding other bases of jurisdiction (double convention in the second sense). Similarly, it is possible to create a convention that deals with both direct and indirect jurisdiction (double convention in the first sense) but does so by only requiring some, not excluding other bases of jurisdiction (simple convention in the second sense).

\section{Mixed Conventions}

This double meaning creates problems for the concept of a mixed convention that have so far gone unnoticed. A mixed convention claims a middle position between single and double conventions. But where the concepts of single and double conventions are ambivalent, such a middle position is impossible to determine. Rather, two criteria compete. The first meaning of "mixed" places the mixed convention between "simple conventions" in the sense that they regulate only indirect jurisdiction and "double conventions" in the sense that they regulate both direct and indirect jurisdiction. In this sense, a mixed convention regulates only indirect (or only direct) jurisdiction for some, both direct and indirect jurisdiction for other jurisdictional bases. The second meaning of "mixed" places the mixed convention between "simple conventions" in the sense that they require some and permit other bases, and "double conventions" in the sense that they both exclude and require certain 
bases, by providing for all three categories: required, permitted, and excluded bases. $47 \mathrm{~A}$ third possibility would be to combine these criteria and to call a convention "mixed" if it is mixed in either of the two senses defined before. Under this approach, simple and double conventions are considered not as whole categories but rather as "two extremes of a spectrum". 48

This ambiguity severely impairs debates on mixed conventions. Obviously, the terminology is both confused and confusing. First, it is not possible to place each possible convention in one or the other category. For example, is an enforcement convention that contains only required and excluded but no permitted bases of jurisdiction a single convention, because it regulates only enforcement? Or is it a double convention, because it contains rules on required and on excluded bases but nothing else? Second, the definitions of the category are not always conclusive. Even von Mehren has explained required bases of indirect jurisdiction in a double convention at one time as permitted bases of direct jurisdiction, 49 another time as required bases of direct jurisdiction..$^{0}$ The practical difference can be considerable. Third, it is hard to discuss the possible substance of a mixed convention and the policy advantage without a clear idea of what it is. The European opposition to the mixed convention may well have been a reaction to such a perceived lack of clarity. This makes clarification desirable.

\section{THE NINE POSSIBLE CATEGORIES For BASES OF JURISDICTION}

If the concepts of simple and double conventions overlap, and if almost all conventions are mixed conventions in one sense or the other, then these three categories of conventions as currently used are not optimal from an analytical perspective and alternative categories are needed. Given that conventions can contain differently structured rules, it makes sense to focus instead on individual jurisdictional bases.

\footnotetext{
47 Ibid. at 19. One could also have named conventions with three different types of jurisdictional bases "triple conventions".

48 von Mehren, Theory and Practice, supra note 40, at 406.

49 von Mehren, New Approach, supra note 2, 282 ("a 'white list' detailing all the bases on which [direct] jurisdiction may be predicated.”, emphasis added); similarly Patrick J. Borchers, Book Review, 39 CREIGHTON L. REv. 995, 996 (2005) ("permissible"), emphases added. For some unclarity regarding the Hague project, see International Jurisdiction and Foreign Judgments in Civil and Commercial Matters - Report drawn up by Catherine Kessedjian, HAGUE CONFERENCE ON PRIVATE InTERNATIONAL LAW - ENFORCEMENT OF JUdGMENTS, PREL. Doc. No. 7 (April 1997), available at http://www.hcch.net/upload/wop/jdgm_pd7.pdf, p. 11, no. 19; see also Haimo Schack, Perspektiven eines weltweiten Anerkennungs- und Vollstreckungsübereinkommens, 1 ZEITSCHRIFT FÜR EUROPÄISCHES PRIVATRECHT [ZEUP] 306, 316 (1993).

$5^{0}$ von Mehren, Design, supra note 2, 19 ("Each Contracting State is required to make available and ... to exercise certain bases of jurisdiction in the international sense," emphasis added)
} 
Usually, the debate is about whether there are only two values of jurisdiction - required and excluded - or whether a third one should be accepted permitted. For example, while the Brussels Regulation contains only required and excluded bases, the 1999 Hague Draft Convention contains provisions for all three values: Articles 3-16 govern required, Article 1751 governs permitted, and Article $18^{5^{2}}$ governs excluded bases of direct jurisdiction. Integrating indirect jurisdiction does not add to the number of categories, since the three lists of indirect jurisdiction in the draft convention are mere extensions of the three lists of direct jurisdiction: a required basis of direct jurisdiction is also a required basis of indirect jurisdiction (Article 25)53; a permitted basis of direct jurisdiction is also a permitted basis of indirect jurisdiction (Article 24) ${ }^{54}$, and an excluded basis of direct jurisdiction is also an excluded basis of indirect jurisdiction (Article 26)55. The Draft Convention thus contains only three different categories of jurisdictional bases: some bases are required both for direct and indirect jurisdiction, some are permitted for both, and some are excluded for both.

This debate over two or three possible values is insufficient. It does not nearly exhaust all possibility, because it does not account for the possibility of treating direct and indirect jurisdiction separately. Once we do this, we see that two dimensions must be distinguished. The first dimension to be distinguished is the value that each basis of jurisdiction can take: required, permitted, and excluded. The second dimension is the kind of jurisdiction regulated, direct or indirect jurisdiction. It follows, in a first step, that a convention can contain six different categories: required, permitted, and

\footnotetext{
${ }^{51}$ Article 17 (Jurisdiction based on national law) provides:

Subject to Articles 4, 5, 7, 8, 12 and 13, the Convention does not prevent the application by Contracting States of rules of jurisdiction under national law, provided that this is not prohibited under Article 18.

52 Article 18 (Prohibited Grounds of Jurisdiction) provides:

1. Where the defendant is habitually resident in a Contracting State, the application of a rule of jurisdiction provided for under the national law of a Contracting State is prohibited if there is no substantial connection between that State and the dispute.

2. In particular, jurisdiction shall not be exercised by the courts of a Contracting State on the basis solely of one or more of the following [followed by a list of exorbitant bases].

53 Art. 25 (Judgments to Be Recognized or Enforced) provides in its first paragraph:

A judgment based on a ground of jurisdiction provided for in Articles 3 to 13, or which is consistent with any such ground, shall be recognised or enforced under this Chapter.

54 Article 24 (Judgments Excluded from Chapter III) provides:

This Chapter shall not apply to judgments based on a ground of jurisdiction provided for by national law in accordance with Article 17.

55 Article 26 (Judgments not to Be Recognized or Enforced) provides:

A judgment based on a ground of jurisdiction which conflicts with Articles 4, 5, 7, 8 or 12, or whose application is prohibited by virtue of Article 18, shall not be recognized or enforced.
} 
excluded bases for direct jurisdiction, and required, permitted, and excluded bases for indirect jurisdiction. ${ }^{6}$

However, once we combine direct and indirect jurisdiction, we see in a second step that the number of possible categories is greater than either three or six. Each basis of jurisdiction can exist in two kinds - as direct and indirect basis. Within each kind, each basis can take on one of three values - it can be required, permitted, or excluded. Taken together, this means that each basis of jurisdiction can, logically, take one of nine $\left(3^{2}\right)$ different forms. The following table illustrates this. The rows represent the three different values a jurisdictional bas can take for direct jurisdiction; the columns represent the three different values a jurisdictional base can take for indirect jurisdiction. In each box, the first value represents direct, the second indirect jurisdiction.

\begin{tabular}{|l|c|c|c|}
\hline & $\begin{array}{l}\text { required } \\
\text { indirect basis }\end{array}$ & $\begin{array}{l}\text { permitted } \\
\text { indirect basis }\end{array}$ & $\begin{array}{l}\text { Excluded } \\
\text { indirect basis }\end{array}$ \\
\hline $\begin{array}{l}\text { required } \\
\text { direct basis }\end{array}$ & $\begin{array}{c}\text { required- } \\
\text { required }\end{array}$ & $\begin{array}{c}\text { required- } \\
\text { permitted }\end{array}$ & $\begin{array}{c}\text { required- } \\
\text { excluded }\end{array}$ \\
\hline $\begin{array}{l}\text { permitted } \\
\text { direct basis }\end{array}$ & $\begin{array}{c}\text { permitted- } \\
\text { required }\end{array}$ & $\begin{array}{c}\text { permitted- } \\
\text { permitted }\end{array}$ & $\begin{array}{c}\text { permitted- } \\
\text { excluded }\end{array}$ \\
\hline $\begin{array}{l}\text { excluded } \\
\text { direct basis }\end{array}$ & $\begin{array}{c}\text { excluded- } \\
\text { required }\end{array}$ & $\begin{array}{c}\text { excluded- } \\
\text { permitted }\end{array}$ & $\begin{array}{c}\text { excluded- } \\
\text { excluded }\end{array}$ \\
\hline
\end{tabular}

Table 1: Nine possible values of jurisdictional bases

This shows that drafters of Conventions have a far greater variety of categories to choose from for bases of jurisdiction - not just two (as in the Brussels Regulation) or three (as in the 1999 Hague Draft Convention), but actually nine. Delegates need not link direct and indirect jurisdiction. Rather, they can decide for each basis of jurisdiction whether it should be required, excluded, or permitted, both for indirect and direct jurisdiction. This finding considerably enhances the possibilities of delegates because it provides them with a considerably greater arsenal of possibilities. Moreover, delegates know that these nine boxes represent all logically possible categories of bases of jurisdiction.

${ }^{56}$ See already von Mehren, Jurisdictional Requirements, supra note 12, at A-37-40. 
Importantly, these nine categories are not just abstract possibilities. To show this, the remainder of this section will illustrate each of them with explication and examples, and start to extrapolate the policies underlying each category.

\section{Required-Required}

The first category comprises bases that are required for both direct and indirect jurisdiction. All bases of jurisdiction listed in Articles 2, $5 \mathrm{ff}$. of the Brussels Regulation are in this category. Member states must provide these bases for direct jurisdiction, 57 and they must enforce decisions based on these grounds (Art. 33, 35(3)). Similarly congruent solutions can be found in other conventions..$^{8}$ U.S. constitutional law contains fewer required bases of direct jurisdiction, though such bases do exist where the U.S. Supreme Court invokes a state's duty to provide a forum ${ }^{59}$. Since the full faith and credit clause obliges other states to enforce such judgments, these bases are also required for indirect jurisdiction.

Required-required bases of jurisdiction provide the most attractive situation possible for plaintiffs: they are guaranteed both that a certain basis of direct jurisdiction exists, and that judgments rendered on these grounds will be enforced elsewhere. Consequently, where delegates agree that a certain basis is desirable, making it required-required is a way to channel litigation to these bases and thus away from other, exorbitant bases of jurisdiction that may merely be permitted-permitted ${ }^{60}$.

\section{Required-Permitted}

The second category of jurisdictional bases is rarer: bases that are required for direct, but only permitted for indirect jurisdiction. One example can be found in the 1965 Hague Convention on Choice of Court. ${ }^{61}$ While it makes

\footnotetext{
57 This rules out even application of the forum non conveniens doctrine: Case C-281/02, Owusu v. Jackson, 2005 E.C.R. I- 1383, no. 37.

$5^{8}$ See, e.g., Convention on Third Party Liability in the Field of Nuclear Energy of 29th July 1960 as amended by the Additional Protocol of 28th January 1964 and by the Protocol of 16 th November 1982, Article 13(a) and (d), available at available at http://www.nea.fr/html/law/nlparis_conv.html.; Convention on the Contract for the International Carriage of Goods by Road (CMR) art. 31(1) and (3), 399 U.N.T.S. 189.

59 Hughes $v$. Fetter, 341 U.S. 609 (1951).

60 von Mehren, Design, supra note 2, at 27.

61 Convention of 25 November 1965 on the Choice of Court, ailable at http://hcch.evision.nl/index_en.php?act=conventions.text\&cid=77. For another example, see Inter-American Convention on Contracts for the International Carriage of Goods by Road, art. 15, available at http://www.oas.org/juridico/english/treaties/b-55.htm.
} 
choice by the parties a required basis for direct jurisdiction, it does not require other states to enforce ensuing judgments - Article 8 only mandates that such judgments shall be recognized and enforced in accordance with national rules. ${ }^{62}$

Required-permitted bases can make sense as an extension of substantive law unification, where delegates want to make sure member states back up the unified substantive law with the provision of effective protection in the courts, but cannot or do not want to regulate enforcement at the same time.

\section{Required-Excluded}

The third category of jurisdiction seems counterintuitive: bases that are required for direct jurisdiction, but excluded for indirect jurisdiction. Yet an example can be found. The Paris Convention of 29 July 1960 on Third Party Liability in the Field of Nuclear Energy ${ }^{63}$ provides, in its Article 13(a), for exclusive direct jurisdiction in the country where the nuclear incident occurred, and makes ensuing judgments enforceable in other member states under its Article 13(d). Article 13(e) bars governments from raising the defense of sovereign immunity against actions brought under Article 13(a), but not against measures of enforcement. In other words, as against state agencies, Article 13 gives both a required basis of direct and an excluded basis of indirect jurisdiction. ${ }^{64}$

A required-excluded basis makes sense where litigation is on the one hand encouraged, so a forum should be provided, but on the other hand the forum state should be the only state where the decision should be enforced. Such a conception simultaneously ensures that victims of governmental acts find a forum for their claims, and that governments maintain their governmental immunity vis-à-vis other countries.

\section{Permitted-Required}

Bases that are permitted for direct and required for indirect jurisdiction form a typical category in simple enforcement conventions, which leave all bases of direct jurisdiction in the gray zone of permitted bases while requiring member states to enforce judgments based on certain required bases of indirect jurisdiction. Articles 10, 11 of the 1971 Hague Judgments Convention contain such bases. The same is true in the U.S. for jurisdictional bases

\footnotetext{
62 See von Mehren, Theory and Practice, supra note 40, at 405 n.130o.

63 Supra, note 58.

64 To be precise, indirect jurisdiction is excluded only against measures of enforcement, not against recognition of foreign judgments.
} 
permissible under the due process clause of the Constitution. Such bases are only permitted, not required: no state is required to offer jurisdiction up to the limits of the Constitution, and some states indeed restrict jurisdiction further ${ }^{65}$. However, decisions rendered by a state in accordance both with domestic law and the due process are entitled to full faith and credit in other states, another way of saying that these bases are required bases of indirect jurisdiction. Finally, Article 4 of the Brussels Regulation turns all jurisdictional bases of member state laws into permitted-required bases of direct jurisdiction ${ }^{66}$. The Brussels Regulation does not require France, for example, to provide jurisdiction for French plaintiffs - Article 4(2) only requires France to treat foreigners domiciled in France the same way as it does French nationals. However, decisions based on such grounds remain enforceable in other member states; the defense of lack of jurisdiction is unavailable. It follows that with regard to domiciliaries of non-member states, not even the Brussels Regulation is therefore a "true" double convention. ${ }^{67}$

Given the rage Article 4 has raised especially among US commentators ${ }^{68}$, the origin of the provision may provide a good example for a situation in which a permitted-required basis seemed appropriate. Besides feeling that competence for direct jurisdiction against third country domiciliaries was lacking, drafters expected the number of cases in which decisions based on exorbitant direct grounds in one member state would be recognized in another was to remain too small to justify an exception from the rule that all indirect bases of jurisdiction are required in order to provide for free movement of judgments ${ }^{69}$. This insight can be generalized. Permitted-required bases are attractive where a free movement of judgments is desired, while a unification of direct bases seems unnecessary because the permitted bases are thought to be relatively harmless.

\footnotetext{
65 For an overview, see Douglas D. McFarland, Dictum Run Wild: How Long-Arm Statutes Extended to the Limits of Due Process, 84 B.U. L. REv. 491, 525-6 (2004)

66 As articulated clearly by von Mehren, Sister-State Judgments, supra note 29, 1058: "the State of origin is entirely free to use any basis for assuming jurisdiction that it chooses, however unfair or unreasonable, while the State addressed cannot impose a jurisdictional requirement but must recognize the resulting judgment."

67 Von Mehren, Design, supra note 2, at 20.

68 E.g. Kurt Nadelmann, Jurisdictionally Improper Fora in Treaties on Recognition of Judgments: The Common Market Draft, 67 CoLUM. L. REv. 995, 1004-6 (1967); von Mehren, Sister-State Judgments, supra note 29, 1057-60; Friedrich K. Juenger, La Convention de Bruxelles du 27 septembre 1968 et la courtoisie internationale. Réflexions d'un américain, 71 REV. CRIT. 37, 41-51 (1983); Juenger, Judicial Jurisdiction in the United States and in the European Communities: A Comparison, 82 MICH. L. REV. 1195, 1211-2 (1984).
}

69 See Michaels, Two Paradigms, supra note 1, at __ with further references. 
The central category of jurisdictional bases is the permitted-permitted category: jurisdictional bases that are neither required nor excluded for either direct or indirect jurisdiction. Conventions traditionally do not contain explicit rules for such bases; the Brussels Regime explicitly avoided any such category in its Article 3. By contrast, the 1999 draft Hague Judgments Convention explicitly provides for a gray category of permitted bases for direct jurisdiction in its Article $17^{70}$ and makes clear in its Article $24^{71}$ that member states remain free to enforce judgments based on such grounds or not.

In a sense, however, conventions with a more limited scope also leave permitted-permitted bases of jurisdiction, namely in the unregulated areas. For example, the 2005 Hague Choice-of-Court convention governs only jurisdiction based on exclusive choice of court agreements. At least under this Convention, non-exclusive choice of court agreements are merely permitted both for direct and indirect jurisdiction; ${ }^{72}$ the same is true for all bases determined through objective criteria. It seems not fully consistent, therefore, if European authors criticized the American proposal of a Hague Convention as overly ambitious for trying to regulate all bases of jurisdiction, and simultaneously feared that the gray list of permitted bases may become too long. All bases of jurisdiction are necessarily regulated in one of the nine ways here described. Ironically, by trying to keep the gray list in the broader Hague Convention as small as possible, Europeans ended up with a far greater gray list than the gray list in 1999 would have been.

This suggests the policy behind such bases: to leave states the greatest freedom possible on controversial bases, because either no agreement can be reached or matters should be left to further development. 73 The permittedpermitted category constitutes the state of nature against which all negotiations towards conventions take place. 74

\footnotetext{
70 Supra note 51.

${ }^{71}$ Supra note 54 .

${ }^{72}$ Art. 22 enables reciprocal declarations between states that would turn such agreements into a permitted-required basis of jurisdiction.

73 Von Mehren, Case, supra note 2, at 91-2.

74 Infra IV.1
} 


\section{Permitted-Excluded}

Permitted-excluded bases of jurisdiction are frequent in single enforcement conventions. A good example is, again, the list of exorbitant bases of jurisdiction in Article 4 of the Supplementary Protocol to the 1971 Hague Judgments Convention. Article 2(1) declares these bases excluded for enforcement purposes. Yet since neither the Convention nor the supplementary protocol regulate direct jurisdiction at all, these bases of direct jurisdiction remain permitted as regards direct jurisdiction. By contrast, the Brussels Regulation and the 1999 Hague Draft Convention contain no permitted-excluded bases of jurisdiction. Under the Brussels Regulation, all bases are required for indirect jurisdiction; under the Hague regime, direct and indirect jurisdiction are symmetric, so what is permitted for direct jurisdiction is permitted also for indirect jurisdiction.

This insight can be generalized. Permitted-excluded bases make sense for conventions that regulate only the enforcement of judgments. While it may seem unusual in two-country relations that country A would demand from country B to refrain from enforcing country A's judgments, it is not implausible to conceive in multi-party relations that country A would want country B to refrain from enforcing judgments rendered in country C. Indeed, such a protection, permitted by Article 59 of the Brussels Convention, 75 constituted the prime interest the U.S. had in negotiating a bilateral enforcement treaty with the U.K. - to prevent the UK from enforcing judgments from other EU member states rendered on exorbitant bases of jurisdiction. ${ }^{76}$ Article 18 of the ensuing draft convention provides precisely such a rule. 77

\footnotetext{
75 Brussels Regulation art. 72 maintains the exception, but only for conventions agreed upon before the Regulation went into force.

${ }^{76}$ Von Mehren, Sister-State Judgments, supra note 29, at 1059-60.

77 Reprinted in David Luther Woodward, Reciprocal Recognition and Enforcement of Civil Judgments in the United States,. the United Kingdom and the European Economic Community, 8 N.C.J. INT'L L. \& COM. 299, 322 (1982/83). Article 18 (1) provides:

Subject to any obligations under a treaty existing at the date of entry into force of this Convention or arising as a result of the accession of further States to such a treaty, a judgment given by a court of other authority of a third State against a person who is a national of a Contracting State or who has a domicile, a place of residence or a place of business, or which is incorporated or has its registered office, in a Contracting State shall be refused recognition or enforcement by the courts of the other Contracting State at the request of the respondent:

(a) where, pursuant to a treaty obligation, the courts of the third State would be precluded from exercising jurisdiction in proceedings against a person having the same connection with the State of the court addressed as the person sued had with the other Contracting State, or

(b) where the judgment would, if it had been given against a person having the same connection with the State of the court addressed, be denied recognition or enforcement on jurisdictional grounds or because proper notice was not given.
} 
Although jurisdictional bases that are excluded for purposes of direct and required for purposes of indirect jurisdiction seem counterintuitive, excluded-required bases are a frequent occurrence. Whenever requested courts are barred from controlling for indirect jurisdiction, all bases of indirect jurisdiction become required bases. This is the situation under Brussels Regulation Art. 35(3), ${ }^{8}$ as the European Court of Justice made clear in its Krombach decision. ${ }^{79}$ A French court had asserted direct jurisdiction based on the plaintiff's French nationality, a direct basis excluded under the Brussels Regulation. Although this basis was excluded for the purpose of direct jurisdiction, the requested German court was barred from invoking the lack of indirect jurisdiction as a barrier to recognition. (Note that under the Brussels Regulation, some other bases that are excluded for direct jurisdiction are also excluded for indirect jurisdiction, namely those regarding insurance and consumer contracts and exclusive jurisdiction, Art. 35(1)).

The Brussels setting suggests what policies underlie excluded-required bases. Where the interest in a free movement of judgments is paramount, as it is in the European Union, the risk that judgments based on excluded direct bases of jurisdiction must be enforced may be deemed lower than the risk of frequent litigation over indirect jurisdiction before the requested court. The risk is smaller here than for permitted-required bases, since if a basis is excluded as a direct basis, the requested court can trust that only very few judgments based erroneously on such a direct basis will have to be recognized. Furthermore, the European Court of Justice can control the exercise of direct jurisdiction. ${ }^{80}$ By contrast, where such strong control at the rendering stage does not exist, or where it is insufficient, excluded-required bases are more problematic.

\section{Excluded-Permitted}

Bases that are excluded for purposes of direct but permitted for purposes of indirect jurisdiction seem counterintuitive, but they exist, especially in conventions that regulate only direct jurisdiction. For example, where parties have chosen a forum, Article 6 of the 1965 Hague Choice of Court Convention excludes all other bases of direct jurisdiction, but it does not simultaneously

78 von Mehren, Jurisdictional Requirements, supra note 12, at A-37.

79 Supra note 45 . For a lucid presentation of the whole Krombach affair, see Andreas F. Lowenfeld, Jurisdiction, Enforcement, Public Policy and Res Judicata: The Krombach Case, in INTERNATIONAL COOPERATION THROUGH PRIVATE INTERNATIONAL LAW - ESSAYS IN MEMORY OF PETER E. NYGH 229 (2004).

${ }^{80}$ von Mehren, Jurisdictional Requirements, supra note 12, at A-29-34. 
exclude recognition of decisions that may nonetheless be grounded on such a basis.

This suggests one policy behind such bases: to protect defendants from litigation, when enforcement seems a negligible risk. Excluded-permitted bases can prevent a tragedy of the commons: States have a mutual interest in avoiding a race to the bottom in which states compete for plaintiffs by offering ever more exorbitant bases of jurisdiction, ${ }^{81}$ yet they may not want to exclude enforcement at the same time. A second policy is the following: Where a jurisdictional basis is excluded only for the sake of another state, it is sufficient to protect that other state with a permitted basis of indirect jurisdiction. In Williams v. North Carolina (II), ${ }^{82}$ the U.S. Supreme Court had to decide whether North Carolina must recognize and enforce a divorce decree that a Nevada court had granted, likely without having jurisdiction (i.e. on an excluded direct basis ${ }^{83}$ ). The Court, held that "North Carolina was not required to yield her State policy..." 84 which seems to imply that North Carolina was very well permitted to yield this policy by enforcing the decree the bases was permitted for indirect jurisdiction.

\section{Excluded-Excluded}

Finally, there are bases of jurisdiction that are excluded for purposes both of direct and of indirect jurisdiction. Such bases do not exist under the Brussels Regime, where all bases are required bases for indirect jurisdiction (with the exceptions of insurance and consumer matters and of exclusive direct jurisdiction, Article 35(1)). They are frequent, however, in other double conventions. One such example can be found in Article 26 of the 1999 Hague Draft Convention, which mirrors the excluded character of bases of direct jurisdiction into indirect jurisdiction. ${ }^{85}$

Excluded-excluded bases provide the maximal protection both for defendants and for countries other than that of the rendering court. By making a jurisdictional basis excluded-excluded, a convention provides a double check that that basis will not be used - first at the stage of the decision, then again at the enforcement stage. This is the strongest way convention delegates have of ruling a certain basis out.

\footnotetext{
${ }^{81}$ Ibid. 404 n.130o.

82325 U.S. 226 (1945).

83 This is a slight simplification from the actual case.

${ }^{84} 325$ U.S. at 239.

85 Supra note 55 .
} 


\section{A NEW TyPOLOGY OF CONVENTIONS}

Although all nine categories are available, many conventions do not make use of all of them. This makes it both possible and worthwhile to devise a typology of such conventions that is both richer and more precise than the trilogy of single, double and mixed conventions. Such a typology can prove helpful in mapping different conventions, in comparing and evaluating them, and in devising new conventions.

\section{State of Nature}

The first type of convention describes the absence of a convention - the state of nature, where all jurisdictional bases are permitted-permitted. Theoretically this could be the substance of a convention, which would provide that each member state is permitted to use or not to use any basis of jurisdiction. However, such a convention would not regulate anything beyond the state of the law without the convention - the "state of nature" of jurisdiction, so to speak. For the purpose of clarity in the following analysis, this special type of conventions will be considered not to be a convention.

Nonetheless, it is crucial to see that the state of nature, in which all jurisdictional bases are prior to any conventions, is not categorically different from the state in which a convention exists. Far from being an anomaly, is instead the default status of all jurisdictional bases. ${ }^{86}$ If von Mehren calls permitted bases of jurisdiction "unregulated", 87 this term should not be read to suggest that permitted bases lie somewhere outside the scope of the law. "Unregulated" is a special category of regulation, too; it just describes what one could call the "state of nature" of jurisdiction. In the parallel study of rights analysis, the state of nature is a state not without legal relations but rather one with only a restricted set of such relations. ${ }^{88}$ Similarly, when the state of nature of jurisdiction is described as "unregulated", this suggests not the lack of legal relations but rather a situation made up of only permitted bases of jurisdiction. ${ }^{89}$ The state of nature is the background against which all negotiations take place, and it is the residual state for all areas in which no agreement can be reached.

Obviously, the state of nature leaves states maximum freedom regarding both exercise of jurisdiction and recognition of foreign judgments, but it leaves the

\footnotetext{
${ }^{86}$ Von Mehren, Design, supra note 2, at 27-8; von Mehren \& Michaels, supra note 8, at 127.

87 Von Mehren, Design, supra note 2, at 25, speaks of "mixed double conventions".

88 Kennedy \& Michelman, supra note 10, at 754-7.

${ }^{89}$ See supra part III.5
} 
reach of their judgments to the mercy of other states. Conventions are negotiated not because of a desire for regulation, but rather because states see a mutual benefit if they exchange this maximum amount of freedom for a greater power of their decisions.

\section{Single and Double Conventions}

A first important typological distinction mirrors the traditional distinction between single and double conventions in the first sense discussed before: 90 single conventions regulate only either jurisdiction or enforcement and double conventions that regulate both. Since such single conventions can come in two versions, depending on whether they regulate jurisdiction or enforcement, ${ }^{11}$ it is more fruitful to distinguish three types: (single) jurisdiction, (single) enforcement, and double conventions.

(Single) jurisdiction conventions contain rules only on direct jurisdiction; all bases of indirect jurisdiction are permitted. In single jurisdiction conventions, all bases of jurisdiction are in boxes 2, 5, and 8. (Single) enforcement conventions contain rules only on indirect jurisdiction; all bases of direct jurisdiction are permitted. In single enforcement conventions, all bases of jurisdiction are in boxes 4,5 , and 6 .

\begin{tabular}{|c|c|c|}
\hline $\begin{array}{c}1 \\
\text { required- } \\
\text { required }\end{array}$ & - & $\begin{array}{c}3 \\
\text { required- } \\
\text { excluded }\end{array}$ \\
\hline permitted- & $\begin{array}{l}5 \\
\text { permitted- } \\
\text { permitted }\end{array}$ & $\begin{array}{l}6 \\
\text { permitted- } \\
\text { excluded }\end{array}$ \\
\hline $\begin{array}{c}7 \\
\text { excluded- } \\
\text { required }\end{array}$ & 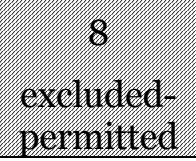 & $\begin{array}{c}9 \\
\text { excluded- } \\
\text { excluded }\end{array}$ \\
\hline
\end{tabular}

Table 2: Single conventions

Possible bases in a single jurisdiction convention

Possible bases in a single enforcement convention

\footnotetext{
${ }^{90}$ Supra part II.3.

${ }^{91}$ Supra note 40.
} 
Double conventions by contrast contain rules both on direct and on indirect jurisdiction. This means, at least one basis of direct jurisdiction and one basis of indirect jurisdiction must be either required or excluded. In other words, the convention must have at least one basis of jurisdiction in the upper or in the lower row of the table or in both (boxes 1-3 and 7-9), and at least one basis of jurisdiction in the left or in the right column of the table or both (boxes $1,4,7$, or $3,6,9$ ). In this sense, the "mixed" convention as proposed by the US delegation for the Hague Judgments Project is a double convention, too. ${ }^{2}$ The Hague Choice of Court Convention is a double convention although it only requires one basis of jurisdiction - jurisdiction based on an exclusive choice-of-court agreement - because this basis is required both for direct and indirect jurisdiction (box 1).

The analysis illustrates how the double meaning of single and double conventions mentioned earlier mars debates: simple and double conventions are often used as incommensurable categories. For example, the Brussels Regulation, often named as the model of a double convention, combines all jurisdictional bases in the left column - boxes 1, 4, and 9. By contrast, a simple enforcement convention does not cover a whole column but rather a whole row; it combines all three bases in the middle column - boxes 4, 5, and 6 . In this sense, double convention and simple convention are incommensurable, they concern different dimensions of jurisdictional bases.

Much has been written about the policies behind single and double conventions. Arthur von Mehren in particular pointed out that double conventions have two requirements that are met both within the EU and within the US: great economic, cultural and legal similarities between the states or countries involved, and a supreme institution (the US Supreme Court viz. the European Court of Justice) to enforce jurisdictional standards in a universal manner.93 In such settings they are attractive because they provide maximum security, while making the enforcement process easy. Single enforcement conventions, by contrast, make sense between countries which are interdependent but lack both strong economic and political bonds and a supreme court.94 More generally speaking, while single enforcement conventions tend to favor plaintiffs, double conventions provide a fuller regime and can therefore provide more information and more balance. 95

\footnotetext{
92 See von Mehren, Design, supra note 2, at 19.

93 Ibid.

94 Von Mehren, Drafting, supra note 2, at 197.

95 von Mehren, Design, supra note 2, at 23-4.
} 


\section{Pure and Mixed Conventions}

A second distinction draws on whether a convention contains only required and excluded bases, or whether it contains permitted bases. In the latter case, it is a mixed convention; in the first case, it will be called, in accordance with von Mehren's use of the word, ${ }^{6}$ a pure convention.

Pure conventions are conventions in which all regulated bases are either required or permitted. Combined with the typology of single and double conventions developed before (sub 2.), there are three types of pure conventions. In pure jurisdiction conventions, all bases are either required or excluded for direct jurisdiction; all bases are therefore in categories 2 and 8.97 In pure enforcement conventions, all bases are either required or excluded for indirect and permitted for direct jurisdiction; all jurisdictional bases are therefore in boxes 4 and $6 .{ }^{8}$ In pure double conventions, finally, all jurisdictional bases are either required or excluded for both direct and indirect jurisdiction;99 all bases are therefore in boxes 1, 3, 7 and 9. The Brussels Regulation is a pure double convention with regard to defendants domiciled in a member state.

\begin{tabular}{|c|c|c|}
\hline $\begin{array}{c}1 \\
\text { required- } \\
\text { required }\end{array}$ & ㄴ. & $\begin{array}{c}3 \\
\text { required- } \\
\text { excluded }\end{array}$ \\
\hline $\begin{array}{l}\text { permitted- } \\
\text { required }\end{array}$ & $\begin{array}{c}5 \\
\text { permitted- } \\
\text { permitted }\end{array}$ & $\begin{array}{l}6 \\
\text { permitted- } \\
\text { excluded }\end{array}$ \\
\hline $\begin{array}{c}7 \\
\text { excluded- } \\
\text { required }\end{array}$ & excluded- & $\begin{array}{c}9 \\
\text { excluded- } \\
\text { excluded }\end{array}$ \\
\hline
\end{tabular}

Table 3: Pure Conventions

Pure jurisdiction convention

96 Ibid. at 25 (also called "full-fledged").

97 That all indirect bases are permitted is irrelevant for the character of a pure convention, the "pure" attribute in a pure jurisdiction convention concerns only bases of direct jurisdiction.

98 Again, that all bases are permitted for direct jurisdiction does not change the pure character.

99 Von Mehren, Design, supra note 2, 19 
Pure enforcement convention

Pure double convention

By contrast, mixed conventions are conventions that contain bases of permitted jurisdiction in addition to required and excluded bases of direct or indirect jurisdiction. ${ }^{100}$ For single conventions, whether jurisdiction or enforcement conventions, this means that at least one basis of jurisdiction must be in box 5 . Double conventions are mixed conventions if they contain a list of permitted bases either for direct or for indirect jurisdiction. The 1999 Hague Draft Convention is a mixed double convention.

Again, Arthur von Mehren has compared the advantages of pure and of mixed conventions. ${ }^{101}$ The great advantage of a pure convention is its clarity regarding the availability or not of any basis of jurisdiction; whereas the great advantage of a mixed convention is that it is easier for delegates to agree upon. However, the analysis has revealed one ostensible disadvantage of the mixed convention to be nonexistent - the idea that a convention with permitted bases is somehow "incomplete". Recognizing permitted as an equally valid value for jurisdiction as required and excluded defeats this criticism. Any convention is complete, because any convention must allocate each basis of jurisdiction into one of the nine categories.

\section{Positive, Negative, and Bivalent Conventions}

Another distinction reformulates and clarifies the distinction between single and double conventions in the first sense discussed before. This distinction draws on whether a convention contains provision only for required (positive conventions), only for excluded (negative conventions), or for both required and excluded bases (bivalent conventions), regardless of any possible permitted bases. A double convention is positive if it contains no excluded bases of jurisdiction; all its bases are thus in boxes 1, 2, 4 and 5. It is radically positive (to use von Mehren's term) ${ }^{102}$ if it contains only required bases, so all bases are in boxes 1, 2, and 4. A positive enforcement convention contains only bases in the two left columns, a radical one only in the left column. A positive jurisdiction convention contains only bases in the upper two rows, a radical one only in the upper row. A double convention is negative if it contains no required bases; all its bases are thus in boxes 5, 6, 8 and 9. It is

100 Ibid.

${ }^{101}$ Ibid. at $25-8$.

102 Ibid. at 21 (calling the Brussels Regulation with regard to defendants not domiciled in a member state a "radical form of the convention simple"). Regarding such defendants, all bases are in category 4; see supra III.4. 
radically negative if all bases are in boxes 6,8 and 9. A negative enforcement convention contains only bases in the two right columns, a radical one only in the right column. A positive jurisdiction convention contains only bases in the lower two rows, a radical one only in the lower row.

For example, the 1971 Hague Judgments Convention without the Supplemental Protocol is a positive enforcement convention. Its Articles 10 and 11 provide a list of required bases of indirect jurisdiction. It is not a radical convention, though - since this list is nonexclusive, all other bases are permitted, none is excluded. However, read together with the Supplemental Protocol, which provides for excluded bases of indirect jurisdiction, the 1971 Convention changes its character to that of a bivalent enforcement convention, because it now contains both required and excluded bases.

\begin{tabular}{|c|c|c|}
\hline 는 & - & $\begin{array}{c}3 \\
\text { required- } \\
\text { excluded }\end{array}$ \\
\hline permitted- & $\begin{array}{l}5 \\
\text { permitted- } \\
\text { permitted }\end{array}$ & $\begin{array}{l}6 \\
\text { permitted- } \\
\text { excluded }\end{array}$ \\
\hline $\begin{array}{c}7 \\
\text { excluded- } \\
\text { required }\end{array}$ & excluded- & $\begin{array}{l}\text { excluded- } \\
\text { excluded }\end{array}$ \\
\hline
\end{tabular}

Table 4: Positive and Negative conventions

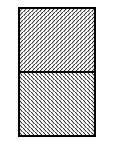

Possible bases in a positive double convention

Possible bases in a negative double convention

Here, the policies go to parties rather than to states. Positive conventions broaden the number of required jurisdictions. They are therefore by definition advantageous to plaintiffs for direct jurisdiction (because plaintiffs, not defendants, determine the forum). Yet they are also potentially advantageous to plaintiffs for indirect jurisdiction, because they broaden the number of places where a judgment can be enforced which the plaintiff, not the defendant, asks for. ${ }^{103}$ By contrast, negative conventions are beneficial to defendants for similar reasons - they can potentially reduce the number of

103 Ibid. at 24-5. 
fora where defendants must defend themselves, and they reduce the number of countries where ensuing judgments can be enforced.

\section{Symmetric and Asymmetric Conventions}

A last bit of terminology must be introduced for a very important characteristic - the symmetric and asymmetric convention. Whether a convention is symmetric draws on the relation between direct and indirect jurisdiction. A convention is symmetric if it treats all jurisdictional bases similarly for direct and for indirect jurisdiction: all bases required for direct jurisdiction are also required for indirect jurisdiction, all bases permitted for direct jurisdiction are also permitted for indirect jurisdiction, and all bases excluded for direct jurisdiction are also excluded for indirect jurisdiction. ${ }^{104} \mathrm{~A}$ convention that contains at least one basis of jurisdiction outside boxes 1, 5, and 9, such as the Brussels Regulation, is an asymmetric convention. Symmetric conventions contain jurisdictional bases only in boxes 1, 5, and 9. ${ }^{105}$ The 1999 Draft Convention is a symmetric convention in this sense; it contains only requiredrequired, permitted-permitted, and excluded-excluded bases of jurisdiction. In a pure symmetric convention, every basis of jurisdiction would be either required or excluded both for direct and for indirect jurisdiction. Note that the Brussels Regulation is not even a pure symmetric convention for defendants domiciled in the EU, because it treats all bases as required for indirect jurisdiction, even if they are required or permitted for indirect jurisdiction. It is symmetric only for insurer and consumer contracts and for exclusive bases of jurisdiction (Art. 35(1)).

\footnotetext{
104 Symmetric single conventions, whether jurisdiction or enforcement jurisdictions, are logically impossible, because the only possible candidate - a convention in which all jurisdictional bases would be permitted both for direct and indirect jurisdiction (box 5) - would be equivalent to the State of Nature, which has been defined not to be a convention (supra IV.1).

105 In this sense, the definition of a mixed convention in von Mehren, Design, supra note 2, at 19, refers to a special type only, namely the symmetric mixed convention.
} 


\begin{tabular}{|c|c|c|}
\hline $\begin{array}{l}1 \\
\text { required- } \\
\text { required }\end{array}$ & $\begin{array}{c}2 \\
\text { required- } \\
\text { permitted }\end{array}$ & $\begin{array}{c}3 \\
\text { required- } \\
\text { excluded }\end{array}$ \\
\hline $\begin{array}{l}4 \\
\text { permitted- } \\
\text { required }\end{array}$ & permitted- & $\begin{array}{c}6 \\
\text { permitted- } \\
\text { excluded }\end{array}$ \\
\hline $\begin{array}{c}7 \\
\text { excluded- } \\
\text { required }\end{array}$ & $\begin{array}{c}8 \\
\qquad \\
\text { excluded- } \\
\text { permitted }\end{array}$ & $\begin{array}{l}9 \\
\text { excluded- } \\
\text { excluded }\end{array}$ \\
\hline
\end{tabular}

Table 5: Symmetric conventions

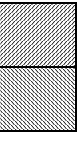

Possible bases in a symmetric convention

Possible bases in a symmetric pure double convention

Given how many Conventions are symmetric, it is understandable if scholars and drafters assume that symmetric conventions are somehow more "natural" than asymmetric conventions. ${ }^{106}$ The conceptual analysis may serve as a healthy antidote against such false assumptions of necessity. Certainly, where general agreement exists over the desirability vel non of a certain basis of jurisdiction, it makes sense to regulate it as required or excluded for both direct and indirect jurisdiction (boxes 1 and 9); where complete disagreement exists, it makes sense to put it (or better: leave it) in the permitted-permitted category (box 5). But the insight that asymmetric conventions are equally possible opens the way for all other values of jurisdiction, and thereby for at least three arguments against symmetry. ${ }^{107}$ First, asymmetric conventions can take a middle position between single and pure double conventions, by regulating certain bases only for direct or only for indirect jurisdiction. Second, the different policy considerations that may apply to direct and indirect jurisdiction ${ }^{108}$ do not require certain bases to be put into the permitted-permitted bases; they can be reflected in an asymmetric convention design. Third, asymmetry can avoid the need to control jurisdiction both in the rendering and in the requested court; ${ }^{109}$ it allows control only at the

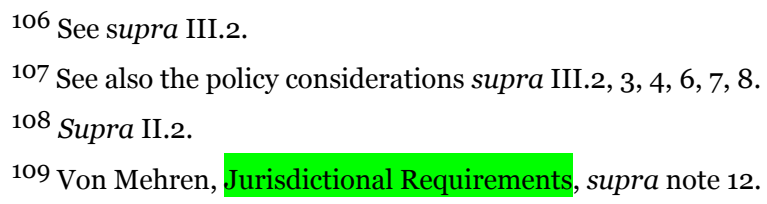


rendering court (as the Brussels Regulation) or only at the requested court (as in a single enforcement convention).

\section{CONSEQUENCES}

It seems certain that delegates at the Hague were unaware of this richness of tools they had at their disposal - categories of jurisdictional bases and types of conventions. Had they realized these, the potential for flexibility in negotiating and drafting would have been much bigger. For example, the U.S. was interested in expanding required bases of indirect jurisdiction in Europe and in reducing permitted bases of jurisdiction in Article 4 of the Brussels Regulation. Europeans, by contrast, were interested in reducing permitted bases of direct jurisdiction in the U.S (like doing business and tag jurisdiction). There was no intrinsic need to link the bases of direct and indirect jurisdiction. Rather, each side could have used its permitted or required bases of direct jurisdiction and its permitted or excluded bases of indirect jurisdiction as bargaining chips in detailed negotiations. There was no need to give each basis the same value for direct and indirect jurisdiction alike. Such detailed negotiations might have led to a piecemeal convention, but that might have been preferable to no convention at all.

Indeed, although this article has focused largely on the necessary conceptual analysis and has left specific application in policy debates for another day, the analysis has three important implications for policy analyses that can be listed here.

First, it broadens considerably the options delegates have. Instead of two or three, they now see nine different possible values for bases of jurisdiction. This should make it easier to find subtle compromises for different issues.

Second, the analysis has the advantage of isolating different issues that imply different considerations. Required bases serve plaintiffs' interests - in finding a forum, and in enforcing ensuing judgments. Excluded bases serve defendants' interests - in avoiding litigation at undesired places, and in reducing the risk of enforcement. Permitted bases are favorable to state interests in maximal freedom, but unfavorable to party interests in predictability and uniformity. Required bases of indirect jurisdiction maximize the power of states to render judgments with extraterritorial effects; excluded bases of direct jurisdiction minimize their privilege to render decisions in the first place. Symmetric regulation of direct and indirect jurisdiction has a strong effect of channeling litigation to or away from such bases; asymmetric regulation enables more subtle regulation. All of these considerations can be assessed specifically for each specific basis of jurisdiction, before the appropriate box can be chosen.

Third, the analysis provides a clearer picture at the macro-level of convention types. The basic insight is that a state of nature (or a situation with only permitted-permitted bases) is not an anomaly but rather the residual status 
against which all negotiations take place. Conventions that regulate both direct and indirect jurisdiction are more complete and more balanced than single conventions but are harder to agree on. Since not all bases of jurisdiction need to be regulated as either required or permitted, mixed conventions are possible that are restricted to the area of agreement. Conventions can be made more plaintiff-friendly or more defendant-friendly depending on whether they contain only required bases (positive conventions) or only excluded bases (negative conventions); they restrict state sovereignty most through excluded bases for direct jurisdiction and required bases for indirect jurisdiction (bivalent conventions). Symmetry between direct and indirect jurisdiction is not a necessary attribute of double conventions; the ability to regulate direct and indirect jurisdiction differently opens a great space of subtle regulation.

This is not the place to speculate in detail what would have been possible at the Hague had delegates been aware of all these possibilities. However, future delegates should be able to realize the full array of possibilities at their hands. It remains to be seen whether they will use it. 